\title{
First Provincial Record of Black-crowned Night heron (Nycticorax nycticorax) in West Sumatra and the Summary of Its Sumatran Records
}

\author{
Muhammad Nazri Janra*, Aadrean, Henny Herwina \\ Department of Biology, Faculty of Mathematics and Natural Science, Universitas Andalas \\ Jl. Kampus Unand Limau Manis, Pauh, Padang, West Sumatra, Indonesia. 25163 \\ *Email: mnjanra@sci.unand.ac.id
}

\begin{abstract}
The Black-crowned Night heron (Nycticorax nycticorax) is a known visitor in Sumatra with more sighting records in the eastern side of the island. Meanwhile, on the west, it was historically recorded from only two offshore islands, namely Nias and Enggano. During the waterbird survey from early 2018 at Pasir Jambak Beach of Padang City in the coastline of West Sumatra, a Night heron was spotted among the colony of mixed egret species. This study aims to update the knowledge of this species in West Sumatra, as well as its general occurrence in Sumatra. This study was conducted by counting the population of each waterbird species found in the research area, while for documentation purposes, a Nikon Coolpix P900 was used to take pictures. Species identification was guided with related books for the Sumatera area. Data then were analyzed and outlined descriptively in accordance with what accumulated from the field survey and online searching. The result showed that the first sighting of Black-crowned Night-heron in West Sumatra follows the common fly-through route of migrant birds in eastern side of Sumatra. The summary of the compiled records of this species indicates that it is probably a vagrant along the western coastline, while it visits more frequently on the eastern side. This is the first record of its kind in the province of West Sumatra, although, previous records cover almost all provinces in Sumatra.
\end{abstract}

Keywords: Ardeidae; Kowak; migrant birds; Nycticorax nycticorax; waterbird species

Article History: Received 20 February 2020; Received in revised form 30 September 2020; Accepted 24 October 2020; Available online 30 December 2020

How to Cite This Article: Janra MN, Aadrean A, Herwina H. 2020. First provincial record of Black-crowned Night heron (Nycticorax nycticorax) in West Sumatra and the summary of its Sumatran records. Biogenesis: Jurnal Ilmiah Biologi. vol 8(2): 133-137. doi: https://doi.org/10.24252/bio.v8i2.12642.

\section{INTRODUCTION}

The Black-crowned Night heron (Nycticorax nycticorax) is widely distributed across the globe with its four known subspecies (del Hoyo et al., 1992). It is recognized by its black crown, nape, and back, which contrasted with its whitish underpart and grey wings and tail (King et al., 1975). The subspecies $N$. $n$. nycticorax spreads from Central and South of Europe eastward to Asia, extending into Indonesian Archipelago, Japan, Africa, and Madagascar. Waterbird census on January 1990 counted 2901 Black-crowned Night-heron at various localities in Indonesia. The breeding colony in Pulau Rambut, off Jakarta Bay is estimated to be at least 4000 (del Hoyo et al., 1992).

In Sumatra, this species is recorded more from the eastern coastline, including the offshore islands. It was sighted as rare visitors in several locations in Lampung (van Marle \& Voous, 1988; Parrott \& Andrew, 1996), South Sumatra (Verheugt et al., 1992), Jambi, North
Sumatra, and Aceh (van Marle \& Voous, 1988; Holmes, 1996). The sighting records were also made from Aruah Islands in Riau Province (van Marle \& Voous, 1988) and Bintan (Rajathurai, 1996); both are located in Malacca Strait. Meanwhile, on the west Sumatran islands, Black-crowned Night-heron was historically recorded from Nias and Enggano Island of Bengkulu (Ripley, 1944; Dymond, 1994; Holmes, 1996). It was not recorded at Mentawai Islands in the offshore of West Sumatra Province (Kemp, 2000), neither from its coastal area (Novarino et al., 2006; Chandra, 2008; Prananta, 2009). Consequently, it was not included in the provincial list of birds in West Sumatra until recently. Therefore, this study aims to update the knowledge of this species in West Sumatra Province, as well as its general occurrence in Sumatra. This is the first record of the existence of Black-crowned Night-heron in West Sumatra. 


\section{MATERIALS AND METHODS}

This study was conducted between May 2017 and April 2018 along the coastline of West Sumatra Province, which included Panjang Island in West Pasaman Regency,
Tiku Beach in Agam, Pasir Jambak Beach in Padang City, the province capital, and Gasan Gadang Beach in Padang Pariaman (Janra et al., 2018).

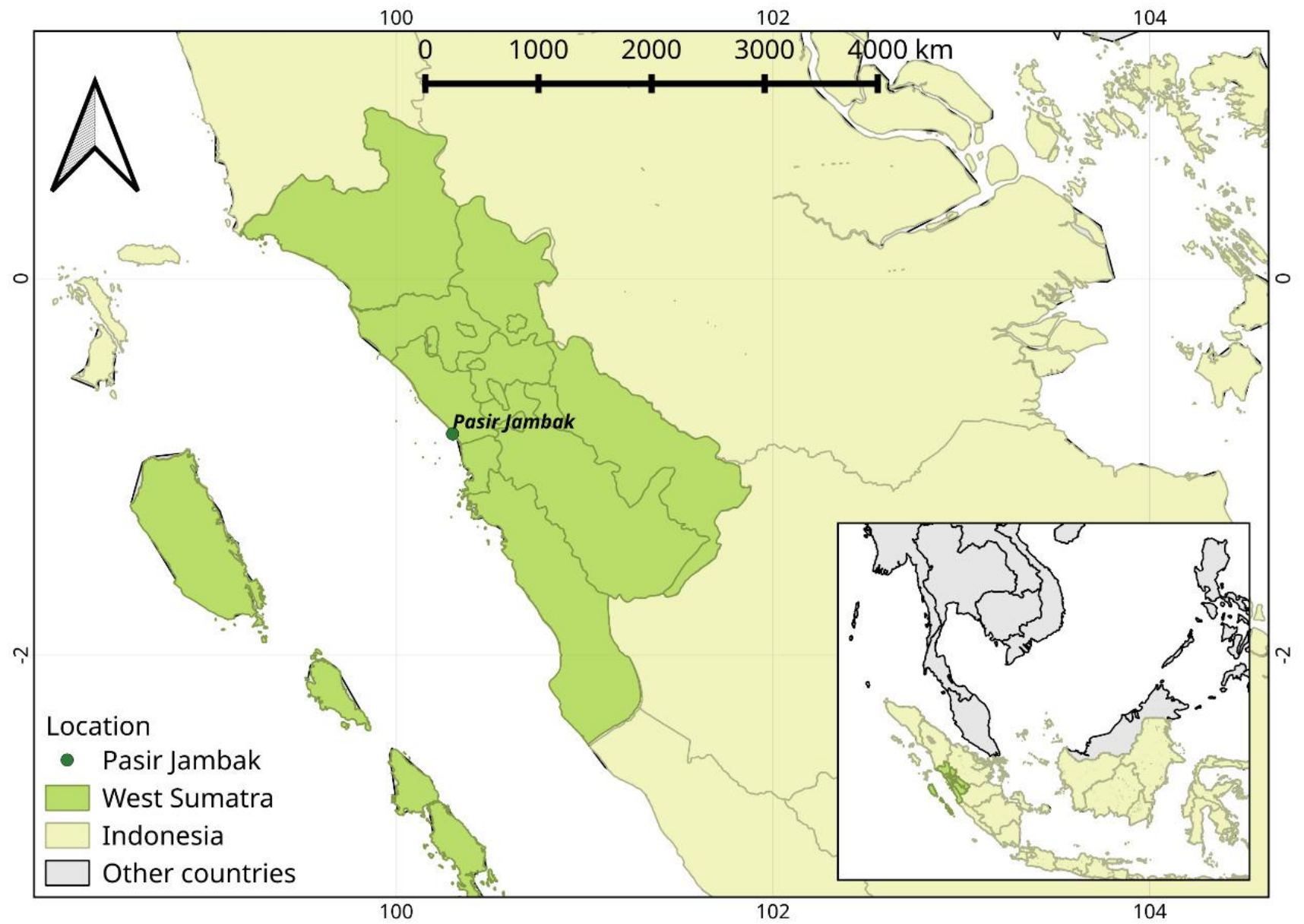

Fig. 1. Location site of Nyxticorax nycticorax

The study was also tailored with Water Bird Census 2018 activity organized by Wetland International - Indonesia Programme. It involved counting the population from each waterbird species. Furthermore, a 10x42 magnification binocular was used to enhance sighting during survey, while for documentation purposes, a Nikon Coolpix P900 was used to take pictures. Species identification was guided with related books for the area (MacKinnon et al., 1998; Eaton et al., 2016). For establishing the historical records on Black-crowned Night heron in
Sumatra, any published record on the species in Sumatra was exhaustively tracked facilitated by online searching engine using a combination of keywords 'Nycticorax nycticorax,' 'Black-crowned Night heron', and 'Sumatra'. The result was then summarized into a table that listed date, location, and other remarks regarding the sighting of species (Table 1). Furthermore, data were analyzed and outlined descriptively in accordance with what accumulated from the field survey and online searching. 
Table 1. Summary of historical and current records of Black-crowned Night-heron Nycticorax nycticorax in Sumatra

\begin{tabular}{|c|c|c|c|}
\hline Date & Location & Source & Remarks \\
\hline \multirow[t]{2}{*}{ 1981-1982 } & Aceh & van Marle \& Voous, 1988 & - \\
\hline & Lhokseumawe & & \\
\hline Sep 1981 & Gunung Leuser Reserve & van Marle \& Voous, 1988 & One adult \\
\hline \multirow[t]{2}{*}{4 Feb 1992} & Meulaboh & Holmes, 1996 & An individual heard \\
\hline & North Sumatra & & \\
\hline 1890 & River Serdang & van Marle \& Voous, 1988 & - \\
\hline 15 Apr 1915 & Ramunia & van Marle \& Voous, 1988 & - \\
\hline 19 Feb 1977 & Percut & van Marle \& Voous, 1988 & - \\
\hline 1891 & Balige & van Marle \& Voous, 1988 & - \\
\hline $1863-1905$ & Nias & Ripley, 1944 & - \\
\hline 28 Sep 1986 & Belawan & Holmes, 1996 & $\begin{array}{l}31 \text { individuals, mostly } \\
\text { immatures }\end{array}$ \\
\hline \multirow[t]{2}{*}{6 Jan - 18 Jun 2011} & Tanjung Rejo & Putra et al., 2015 & $\begin{array}{l}\text { Averagely } 3637 \text { individual } \\
\text { per month observed }\end{array}$ \\
\hline & Jambi & & \\
\hline July 1986 & Coastal Swamp & van Marle \& Voous, 1988 & One individual \\
\hline \multirow[t]{2}{*}{5 Sep 1986} & Batang Hari River & Holmes, 1996 & - \\
\hline & West Sumatra & & \\
\hline \multirow[t]{2}{*}{ 6-7 Jan 2018} & Padang Beach & This study & One individual \\
\hline & Bengkulu & & \\
\hline \multirow[t]{2}{*}{1944} & Enggano & Ripley, 1944 & $\begin{array}{l}\text { Two males, one female } \\
\text { collected }\end{array}$ \\
\hline & Riau & & \\
\hline \multirow[t]{2}{*}{ Nov 1906} & Aruah Islands & van Marle \& Voous, 1988 & - \\
\hline & Riau Islands & & \\
\hline \multirow[t]{2}{*}{25 Apr 1994} & $\begin{array}{l}\text { Tanjung Bintan \& Tanjung } \\
\text { Tondang }\end{array}$ & Rajathurai, 1996 & $\begin{array}{l}\text { Voice recorded at two } \\
\text { different sites }\end{array}$ \\
\hline & South Sumatra & & \\
\hline \multirow[t]{2}{*}{20 Mar 1989} & Tanjung Koyan & Verheugt et al., 1992 & One individual \\
\hline & Bangka Belitung & & \\
\hline \multirow[t]{2}{*}{1863} & Bangka & van Marle \& Voous, 1988 & - \\
\hline & Lampung & & \\
\hline May 1976 & Tanjung Karang & van Marle \& Voous, 1988 & - \\
\hline Jan 1977 & Menggala & van Marle \& Voous, 1988 & - \\
\hline \multirow[t]{2}{*}{ Oct 1978} & Way Kambas Reserve & van Marle \& Voous, 1988 & Marked as rare (see also \\
\hline & & & Parrot \& Andrew, 1996) \\
\hline 19-24 Mar \& 11-16 & Rawa Pacing, Lampung & Holmes \& Noor, 1995 & Breeding colony with \\
\hline May 1994 & & & estimated total population \\
\hline & & & 3354 individuals \\
\hline
\end{tabular}

\section{RESULTS AND DISCUSSION}

The sighting of Black-crowned Nightheron. On January 6, 2018, a survey was conducted at nipa-palm (Nypa fruticans) clusters within Pasir Jambak Beach of Padang (Fig. 1), which was part of the waterbird survey series. This clump of nipa-palm vegetation is known as the breeding site for mixed colonies of Cattle Egret Ardea ibis, Intermediate Egret Ardea intermedia, Little Egret Egretta garzetta, and Striated Heron Butorides striata. Furthermore, black-crowned Night-heron is distinguished from Striated Heron from its bigger size, two prolong black plumes on its head, and prominent white underparts (Fig. 2).
Rufous Night-heron (Nycticorax caledonicus), another Nycticorax member in Indonesian Archipelago, is different from its rufous or reddish brown upper wing covert (MacKinnon et al., 1998), which was previously not recorded in Sumatra until 2000 (Iqbal \& Takari, 2006).

Around $9.30 \mathrm{~h}$, at the approximate of the center of nipa palm cluster, at a barren tip of a nipa midrib, a Black-crowned Night-heron was sighted among the breeding and nest building egrets. It was immediately identified to be different from other surrounding white egrets through its typical silhouette and coloration of black upperparts, whitish underpart, and grey wings. It was perching silently during the 
observation, did not make any aggressive gesture, and was not agitated by other flyingthrough birds. It stayed at the perch until the observer left the site an hour later. Subsequent observation made on the next day re-spotted the presumably same individual perching at around the same place and time. No other individual was observed until the waterbird survey concluded in April 2018.

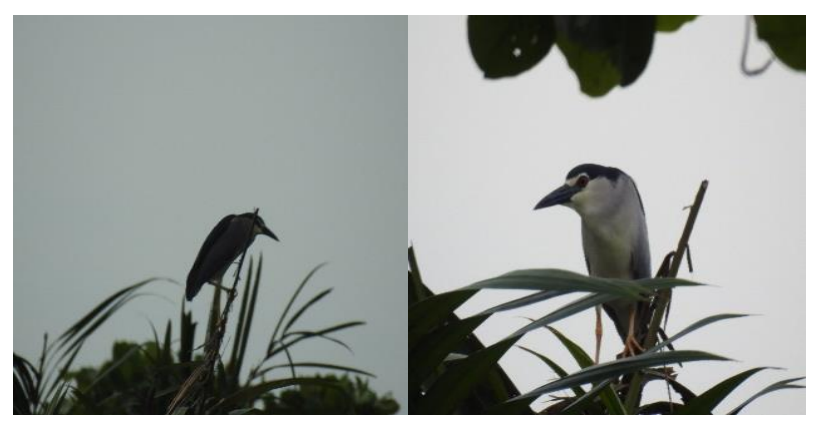

Fig. 2. Black-crowned Night-heron in Sumatra

Historical Records of Black-crowned Night-heron in Sumatra. The most comprehensive account on Sumatran birds compiled by van Marle \& Voous (1988) provides an array of historical records for Black-crowned Night-heron in this island. The literature search was extended using online repository in biodiversity library website (www.biodiversitylibrabry.org), to find any necessary detail regarding the historical records of this species. Most of the records after the 1990s were published in Kukila Journal of Indonesian Ornithologists's Union.

There are 21 published records on Blackcrowned Night-heron before the current West Sumatran sighting (Table 1). North Sumatra was with the highest (7 records), followed by Lampung (4 records) and Aceh (3 records). Three originated from the western coastline of Sumatra; Meulaboh (Holmes, 1996), Nias and Enggano Island (Ripley, 1944). These reports concern only one to several individuals sighted or heard. The rest of the records are from the eastern coastline of Sumatra, including two reports of individual counts in thousand. These include the 3637 individuals counted monthly at Tanjung Rejo, northeast of North Sumatra, and a population estimate of 3354 at Rawa Pecing, northeast of Lampung.
This is probably the first direct sighting record of vagrant Black-crowned Night-heron on west Sumatran coastline, as the previous were from the offshore island (Ripley, 1944), or recorded through vocalization (Holmes, 1996). The sighting of this bird among the breeding colony of egrets indicates its preference for roosting in aggregation with other Ardeidae species. This is because the roosting and breeding colony of Black-crowned Night-heron was frequently reported to intermingle with sites of darters, egrets, and other herons (Lambert \& Erftemeijer, 1989; Mardiastuti et al., 2018).

In Indonesia, Black-crowned Night-heron breeds mainly in Java and Borneo (van Marle \& Voous, 1988; Robson, 2011; Eaton et al., 2016). The colonies in Pulau Rambut and Pulau Dua, on the offshore of West Java, were probably the largest breeding aggregation in Sunda region (del Hoyo et al., 1992). One record from Lampung was based on the observation of birds in captivity (Holmes \& Noor, 1995), while the individual colonies were suspected more as visitors from Pulau Dua and Pulau Rambut (van Marle \& Voous, 1988).

The data on the historical records of Blackcrowned Night-heron suggests that the visiting flocks tend to fly through the eastern part of Sumatra than of the west. It is due to the main concentration of water birds and shorebirds in Sumatra (Crossland et al., 2006). This relates to the habitat condition in the eastern side with wide intertidal mudflat zone that provides more resources for huge flock (Brown \& Sherry, 2006; Whitten et al., 2009). Western Sumatra tends to be steeper terrain and with a limited intertidal surface, reducing habitat capacity to support aggregation of water birds (Ripley, 1944; Crossland et al., 2006). Furthermore, the sighting of a Black-crowned Night-heron in the West of this Province is the last piece that completes the puzzling distribution of this species in Sumatra. Further observation, however, is needed to establish its firm status in west Sumatran coastline. Nevertheless, it is currently safe to maintain its status as vagrant in this island. 


\section{CONCLUSION}

The first sighting of Black-crowned Nightheron Nycticorax nycticorax in West Sumatra Province completed the records for this species in all demographic area of Sumatra. The summary of all published sighting on this species suggests that it follows the common flythrough route of migrant birds in eastern side of Sumatra. Therefore, this bird should be considered as a vagrant in West Sumatra and probably in all parts of the coastline.

\section{ACKNOWLEDGEMENTS}

We thank to Ferry Atmaja and the members of KCA-LH Rafflesia FMIPA Universitas Andalas who helped the shorebird surveys as well as providing some logistics. We thank Fundamental Research Scheme (Contract No. 27/UN. 16.17/PP.RD/LPPM/2018) for financial support of this survey.

\section{REFERENCES}

Brown DR, Sherry TW. 2006. Food supply controls the body condition of a migrant bird wintering in the Tropics. Oecologia. vol 149(1): 22-32. doi: https://doi.org/10.1007/s00442-006-0418-z.

Chandra R. 2008. Jenis-jenis burung di Pulau Marak Pesisir Selatan Sumatera Barat. [Skripsi]. Padang: Universitas Andalas.

Crossland AC, Sinambela SA, Sitorus AS, Sitorus AW. 2006. An overview of the status and abundance of migratory Waders in Sumatra, Indonesia. Stilt. vol 50: $90-95$.

Dymond N. 1994. A Survey of the Birds of Nias Island, Sumatra. Kukila. vol 7(1): 10-27.

Eaton JA, van Balen S, Brickle NW, Rheindt FE. 2016. Birds of the Indonesian Archipelago Greater Sundas and Wallacea. Barcelona: Lynx Edicions. p. 496.

Holmes DA, Noor YR. 1995. Discovery of waterbird colonies in North Lampung, Sumatra. Kukila. vol 7(2): 121-128.

Holmes DA. 1996. Sumatra bird report. Kukila. vol 8: 956.

del Hoyo J, Elliott A, Sargatal J, Christie DA. 1992. Handbook of the Birds of the World. Volume 1: Ostriches to Ducks. Barcelona: Lynx Ediciöns. p. 696.

Iqbal M, Takari F. 2006. Probable first record of Japanese Night-heron Gorsachius goisagi for Sumatra. Kukila. vol 13: 77-78.
Janra MN, Mursyid A, Aadrean, Indra G, Ringga M, Ikhsan M. 2018. Shorebird surveys at the Coast of West Sumatra Province, Indonesia: 2017-2018. Stilt. vol 72: 27-32.

Kemp N. 2000. The birds of Siberut, Mentawai Islands, West Sumatra. Kukila. vol 11: 73-96.

King B, Woodcock M, Dickinson EC. 1975. A field guide to the birds of South-East Asia. London: Collins. p. 480.

Lambert F, Erftemeijer P. 1989. The waterbirds of Pulau Rambut, Java. Kukila. vol 4(3-4): 109-118.

MacKinnon J, Phillipps K, van Balen S. 1998. BurungBurung di Sumatera, Jawa, Bali dan Kalimantan. Indonesia: Pusat Penelitian dan Pengembangan (Puslitbang) Biologi-LIPI Bogor. p. 509.

Mardiastuti A, Mulyani YA, Suratno. 2018. Waterbird community in a plantation forest of an industrial area. Proceeding of the $2^{\text {nd }}$ International Conference on Bioscience (ICoBio). August 8-10, 2017. Bogor: Department of Biology, FMIPA IPB. IOP Conf. Series: Earth and Environmental Science. vol 197: 1-7. doi: 10.1088/1755-1315/197/1/012024.

Novarino W, Noske R, Salsabila A, Jarulis. 2006. A mistnetting study of birds in Lunang Freshwater Swamp Forest, West Sumatra. Kukila. vol 13: 48-63.

Parrott S, Andrew P. 1996. An annotated checklist of the birds of Way Kambas National Park, Sumatra. Kukila. vol 8: 57-85.

Prananta R. 2009. Jenis-jenis burung di kawasan Pantai Carocok Painan Kbupaten Pesisir Selatan. [Skripsi]. Padang: Universitas Andalas.

Putra CA, Hikmatullah D, Prawiradilaga DM, Harris JBC. 2015. Surveys at Bagan Percut, Sumatra, reveal its international importance to migratory Shorebirds and Breeding Herons. Kukila. vol 18(2): 46-59.

Rajathurai S. 1996. The birds of Batam and Bintan Islands, Riau Archipelago. Kukila. vol 8: 86-113.

Ripley SD. 1944. The bird fauna of the West Sumatran Islands. Bulletin of the Museum of Comparative Zoology. vol 94(8): 305-430.

Robson C. 2011. Field guide to the birds of South-East Asia. Wahroonga: New Holland Australia. pp. 544.

van Marle JG, Voous KH. 1988. The birds of Sumatra: An annotated checklist. Peterborough: British Ornithologists' Union. p. 265.

Verheugt WJM, Skov H, Danielsen F. 1992. Notes on the birds of the tidal lowlands and floodplains of South Sumatra province, Indonesia. Kukila. vol 6(2): 5384.

Whitten T, Damanik SJ, Anwar J, Hisyam N. 2009. The ecology of Sumatra. $2^{\text {nd }}$ ed. Yogyakarta: Gadjah Mada University Press. p. 512. 